\title{
Analisis Implementasi Konsep Nafkah dalam Upaya Meningkatkan Kesejahteraaan Perekonomian Keluarga di Desa Karangsari Kecamatan Kembaran Kabupaten Banyumas
}

\author{
Shofiyulloh \\ Universitas Islam Negeri Prof. K. H. Saifuddin Zuhri Purwokerto, Indonesia \\ shofiyulloh_syaubari@iainpurwokerto.ac.id
}

Copyright (C) 2021 The Author

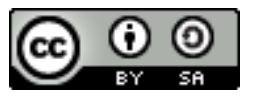

This is an open access article

Under the Creative Commons Attribution-ShareAlike 4. 0 International License

\begin{abstract}
Karangsari Village is a village located in the Banyumas Regency, Central Java. From existing data, one third of the population is in the poverty line. Even though almost all of its territory is relatively fertile agricultural land, but it is not supported by quality human resources, due to the low level of education due to dropping out of school. from this it can be concluded that when the head of the family has a low education, the impact is that the provision of a living is the main axis in building family welfare. This study critically analyzes the responsibilities of a husband as the head of the family in his role in realizing the family's economic welfare. The responsibility to provide a living is a consequence that must be carried out by the husband after the marriage. In other words, this study aims to provide a general view that the implementation of a living is considered capable of alleviating poverty in the family environment. The more a husband realizes the obligation of living and tries to fulfill it, it means that he can build and nurture a family well in economic prosperity. Through the analysis of basic needs, this study traces the economic welfare of the family which is influenced by the awareness of the responsibilities of living, which includes the needs of clothing, food and housing. The implication of this research is the necessity to optimize the concept of living in improving the economic welfare of the family.
\end{abstract}

Keywords: concept of livelihood; poverty; economic improvemet; family

\begin{abstract}
ABSTRAK
Desa Karangsari merupakan pedesaan yang berada di wilayah Kabupaten Banyumas, Jawa Tengah. Dari data yang ada, sepertiga penduduknya berada di garis kemiskinan. Padahal hampir seluruh wilayahnya adalah tanah pertanian yang relatif subur, namun tidak didukung sumber daya manusia yang berkualitas, dikarenakan pendidikan yang rendah akibat putus sekolah. Dari sini dapat disimpulkan bahwa ketika kepala keluarga memiliki pendidikan rendah dampaknya adalah kurang optimalnya pemberian nafkah sebagai poros utama dalam membangun kesejateraan keluarga. Penelitian ini menganalisis secara kritis tanggungjawab yang diemban seorang suami sebagai kepala keluarga dalam perannya untuk mewujudkan kesejahteraan ekonomi keluarga. Tanggungjawab memberi nafkah merupakan konsekuensi yang harus diemban oleh suami setelah adanya pernikahan. Dengan kata lain, penelitian ini bertujuan untuk memberi pandangan umum bahwa implementasi nafkah dianggap mampu mengentaskan kemiskinan di lingkungan keluarga. Semakin seorang suami menyadari kewajiban nafkah dan berusaha memenuhinya, berarti ia dapat membangun dan membina keluarga dengan baik dalam kesejahteraan ekonomi. Melalui analisis kebutuhan dasar, penelitian ini
\end{abstract}


menelusuri kesejahteraan perekonomian keluarga di Desa Karangsari yang dipengaruhi adanya kesadaran tanggung jawab nafkah, yang meliputi kebutuhan sandang, pangan dan papan. Implikasi dari penelitian ini adalah adanya keharusan untuk mengoptimalkan konsep nafkah dalam meningkatkan kesejahteraan perekonomian keluarga.

Kata Kunci: konsep nafkah; kemiskinan; peningkatan perekonomian; keluarga

\section{A. PENDAHULUAN}

Kemiskinan adalah masalah kemanusiaan yang sampai saat ini masih menjadi isu sentral di belahan bumi manapun. Setiap pemimpin negara selalu didorong untuk dapat memberikan kesejahteraan kepada rakyat yang dipimpinnya. Menurut Johan Arifin (2020), pengentasan kemiskinan menjadi langkah penting dalam Rencana Pembangunan Jangka Panjang Nasional (RPJPN 2005-2025). Menurutnya, rencana pembangunan dalam pengentasan kemiskinan yang digagas oleh pemerintah tersebut dianggap mampu menurunkan angka kemiskinan, walaupun penduduk yang tergolong miskin masih signifikan (Johan Arifin, 2020).

Sementara itu, Tyas Eko Raharjo F (2013) menjelaskan bahwa penyebab kemiskinan secara konseptual terdapat empat faktor, yaitu: pertama, faktor individual, yaitu bahwa orang miskin terbentuk oleh sikap, langkah atau kesiapan dalam manjalani kehidupan. Kedua, faktor sosial, yaitu bahwa situasi dan kondisi sosial yang mendorong orang tersebut jatuh dalam kemiskinan. Ketiga, faktor kultural, kemiskinan kultur atau budaya kemiskinan memiliki gambaran adanya kesinambungan antara kemiskinan dengan kebiasaan hidup yang dijalani. Keempat, faktor struktural, yaitu mengarah pada struktur atau sistem yang tidak memiliki keberpihakan terhadap adanya kemiskinan.

Menurut Sutandyo Wigjosoebroto (2005), setidaknya terdapat dua hal yang mendorong adanya kemiskinan, yaitu kemiskinan yang alami dan buatan. Kemiskinan alami terjadi akibat kondisi alam yang terbatas, teknologi yang minim dan berada di wilayah rawan bencana alam. Sedangkan kemiskinan buatan muncul karena adanya kebijakan yang tidak representatif, yang pada akhirnya mengalami kesusahan dalam menghindari kemiskinan. Oleh sebab itu, setiap pemimpin wajib memprioritaskan wacana kemiskinan dan berikut dengan programnya pada setiap kebijakannya.

Pada umumnya, langkah awal untuk peningkatan perekonomian dalam upaya pengentasan kemiskinan dimulai dari lingkungan keluarga. Dalam keluarga Islam, seorang suami dituntut untuk memikirkan dengan baik bagaimana keluarganya sejahtera dengan pemberian nafkah (Farida Hidayati et al, 2012). Terlebih lagi, al-Quran menyebutkan mengenai peringatan akan kesejahteraan anak keturunan dalam Q.S. an-Nisa: 9. Ayat tersebut secara tidak langsung memberikan gambaran bahwa mengantisipasi adanya kelemahan perekonomian keluarga, kurangnya pelayanan terhadap kesehatan fisik dan kelemahan intelegensi anak dan kekurangan makanan yang bergizi, merupakan tanggung jawab kedua orang tuanya, khususnya suami sebagai kepala rumah tangga.

Untuk mewujudkan tanggungjawab tersebut, Islam memberlakukan aturan nafkah bagi suami untuk diberikan kepada istri dan seluruh anggota keluarga yang berada di bawah pertanggungjawabannya. Menurut Wahbah az-Zuhali (1989), kewajiban nafkah diperuntukkan 
pada tiga hal, yaitu makanan, pakaian, dan tempat tinggal. Senada dengan itu, Kompilasi Hukum Islam (KHI) yang berlandaskan Instruksi Presiden Nomor 1 Tahun 1991, Pasal 80 ayat (4) menegaskan bahwa suami menanggung nafkah pakaian, tempat tinggal bagi isteri, biaya rumah tangga, biaya perawatan dan biaya pengobatan bagi istri dan anak, serta biaya pendidikan bagi anak (Abdurrahman, 1992). Oleh sebab itu, syariat pernikahan bukan sesuatu yang sederhana, bukan pula hanya mengandalkan cinta kasih antara kedua pasangan calon suami dan istri, tetapi lebih daripada itu, yaitu harus siap lahir dan batin. Bagi seorang suami, kewajiban nafkah merupakan bentuk perhatian dan peran aktifnya terhadap kesejahteraan dan peningkatan perekonomian keluarga. Jadi, dapat dikatakan bahwa kategori orang dikatakan miskin adalah ketika seseorang atau kepala rumah tangga tidak mampu memenuhi kebutuhan pokok pada umumnya, seperti: sandang, pangan, papan, kesehatan, dan pendidikan (Chriswardani Suryawati, 2005).

Implikasi konsep nafkah ini pada dasarnya memberikan dampak positif terhadap perekonomian keluarga, termasuk keluarga di Desa Karangsari. Berdasarkan data penelitian ini, angka putus sekolah di Desa Karangsari lebih cenderung dikarenakan kemiskinan, yang pada akhirnya pemberian nafkah kurang maksimal. selanjutnya, permasalahan menjadi semakin kompleks ketika implementasi konsep nafkah bergantung pada sumber daya manusia (SDM) yang unggul, sedangkan SDM yang unggul bergantung pada tingkat pendidikan yang tinggi sekaligus melakukan upaya pencegahan terhadap angka putus sekolah.

Dari pemaparan di atas dapat disimpulkan bahwa penelitian ini mengupayakan adanya implementasi konsep nafkah pada setiap keluarga dalam rangka mewujudkan kesejahteraan perekonomian bagi anggota keluarganya. Di samping itu, penelitian ini memberikan beberapa gambaran, di antaranya: pertama, keadaan masyarakat Karangsari yang secara umum masih tergolong miskin, baik dilihat dari sumber daya manusianya maupun tidak tersedianya fasilitas ekonomi yang memadai, sehingga menjadi penghalang setiap keluarga untuk mengembangkan kesejahteraan anggota keluarganya. Kedua, mengupayakan peluang untuk mengubah mindset setiap keluarga di Desa Karangsari dalam mengembangkan potensi keluarga yang dimiliki melalui implementasi konsep nafkah. Ketiga, perlu upaya dari para tokoh agama dalam memberikan materi penyuluhan melalui Majelis Taklim yang ada di Desa Karangsari berkaitan dengan upaya mengembangkan potensi keluarga dalam pengentasan kemiskinan yang berakar dari implementasi konsep nafkah yang kurang optimal.

\section{B. KAJIAN PUSTAKA}

\section{Masalah Kemiskinan di Pedesaan}

Kemiskinan dideskripsikan sebagai suatu kondisi ketidakmampuan sisi ekonomi untuk memenuhi kebutuhan dasar manusia, yakni sandang, pangan, dan papan. Dengan demikian, kemiskinan lebih identik dengan kelaparan, tempat tinggal yang tidak layak, putus sekolah, sehingga mengakibatkan berkurangnya hak untuk hidup, terpinggirkan, dan merasa bahwa masa depannya suram. Untuk itu, banyak peneliti melakukan upaya penelusuran terhadap penyebab, dampak dan sekaligus solusi untuk mengentaskan kemiskinan. 
Ichsan Sevrianda dan Dewi Zaini Putri (2018) melakukan penelitian yang menghasilkan beberapa temuan sebagai berikut. Pertama, pendidikan memiliki pengaruh negatif dan signifikan terhadap kemiskinan (di Provinsi Sumatera Barat) dengan prosentase sebesar $10 \%$. Logikanya bahwa semakin banyak kepala rumah tangga yang berpendidikan Sekolah Dasar maka semakin besar peluang rumah tangga tersebut miskin. Kedua, jumlah anggota rumah tangga berpengaruh negatif dan signifikan terhadap kemiskinan dengan prosentase sebanyak 10\%. Logikanya bahwa semakin banyak jumlah anggota rumah tangga maka semakin besar jumlah tanggungan yang pada akhirnya dapat berpengaruh kepada besarnya pengeluaran rumah tangga tersebut. Ketiga, status pekerjaan berpengaruh negatif dan signifikan terhadap kemiskinan dengan prosentase sebanyak 10\%. Logikanya, ketika kepala rumah tangga memiliki pekerjaan dengan penghasilan yang layak, maka perekonomian rumah tangga membaik dan tingkat kemiskinan keluarga menurun. Keempat, usia berpengaruh positif dan signifikan terhadap kemiskinan dengan prosentase sebanyak 10\%. Dengan logika, Produktifitas seseorang dalam bekerja dipengaruhi oleh usia, sehingga apabila usia seseorang berada pada usia produktif maka dapat menghasilkan lebih banyak output pekerjaan (Ichsan S. \& Dewi Z.P., 2018).

Sementara itu, penelitian tentang kemiskinan di pedesaan pernah juga dilakukan oleh Ikawati dan Sri Wahyuni (2016). Dalam penelitian itu disebutkan bahwa kemiskinan dibedakan dalam dua hal, yaitu: pertama, kemiskinan digambarkan sebagai gejala ekonomi yang pada akhirnya tidak mampu memenuhi kebutuhan pokok. Kedua, kemiskinan budaya, yaitu kemiskinan mayoritas terletak pada manusia itu sendiri, semisal gaya hidup, kebiasaan hidup dan langkah sosial lainnya. Selanjutnya, dapat dijelaskan bahwa kemiskinan bersifat multidimensional, sehingga kemiskinan tidak hanya diukur dari pendapatan keluarga saja, melainkan juga meliputi kerentanan dan kerawanan, serta keterbatasan masyarakat miskin dalam mengakses penetapan kebijakan publik (Ikawati, \& Sri Wahyuni, 2016).

Selanjutnya, Cica Sartika, dkk. (2016) mengutip ungkapan yang disampaikan oleh Ginanjar Kartasasmita (1996), bahwa kemiskinan suatu daerah dapat dikelompokkan ke dalam: pertama, persistent proverty, yaitu kemiskinan yang kronis atau turun-temurun. Kemiskinan semacam ini disebabkan oleh krisis sumber daya alam atau berada di daerah yang terisolasi. Kedua, cyclical proverty, yaitu kemiskinan terjadi pada pola siklus ekonomi secara keseluruhan. Ketiga, seasonal proverty, yaitu kemiskinan yang terjadi karena siklus musim yang mengalami perubahan. Keempat, eccidental proverty, yaitu kemiskinan diakibatkan adanya bencana alam. Di sisi lain, penelitian ini menyimpulkan bahwa beberapa faktor penyebab terjadinya kemiskinan adalah di antaranya tingkat umur; besarnya beban tanggungan keluarga; rendahnya tingkat pendidikan dan keterampilan, rendahnya tingkat pendapatan, dan sarana produksi yang masih sederhana serta etos kerja yang rendah (Cica Sartika, dkk.,2016).

Berangkat dari beberapa literatur di atas, penelitian ini mengidentifikasi tingkat kemiskinan pada masyarakat di Desa Karangsari Kecamatan Kembaran Kabupaten Banyumas. Sisi distingsi penelitian ini dengan yang lain adalah pemaparan konsep nafkah 
sebagai salah satu pengaruh yang signifikan bagi adanya kesejahteraan keluarga. Karena pada umumnya kemiskinan sering dipotret melalui gejala sosial, kali ini akan diprotret melalui pendekatan syariat nafkah.

\section{Konsep Nafkah}

Al-Quran Surat Al-Thalaq: 6-7 memberikan gambaran umum, yaitu: pertama, nafkah itu diberikan kepada istri berkaitan dengan tempat tinggal menurut yang patut dan berdasarkan kemampuan dari suami. Kedua, dalam hal istri hamil sampai melahirkan, suami diwajibkan memberikan nafkah kepada istri. Ketiga, istri berhak mendapat nafkah sebagai upah menyusui dan merawat anak. Keempat, jika ada kesulitan dalam hal nafkah dianjurkan untuk bermusyawarah antara suami dan istri. Kelima, dalam hal memberi nafkah, tetap mempertimbangkan kemudahan dan menghindari kesulitan atau mudarat. Karena tidak semua suami memiliki kemampuan untuk memberikan nafkah pada seluruh sendi kehidupan.

Sementara itu, dalam beberapa literatur, penelitian mengenai konsep nafkah pernah dilakukan oleh Adam Sugiarto, dkk. (2016). Penelitian tersebut menjelaskan bahwa ada dua strategi nafkah keluarga petani di Kecamatan Playen Kabupaten Gunungkidul sebagai beriukt. Pertama, strategi nafkah tunggal, yaitu dengan cara bertani di sawah, di ladang dan di kebun, beternak, serta menanam pohon jati. Kedua, strategi nafkah campuran, yaitu dengan cara bertani sambil berwiraswasta, ada juga istri menjadi PNS, salah satu anggota keluarga ada yang melaksanakan migrasi, dan lain sebagainya. Dari dua strategi tersebut, tujuh dari sepuluh keluarga petani menyupayakan strategi nafkah campuran. Kesimpulan berikutnya adalah tingkat kesejahteraan keluarga tergolong ke dalam kategori tidak sejahtera. Selanjutnya, kesejahteraan keluarga petani juga dipengaruhi oleh usia suami, pendapatan per kapita keluarga, dan besarnya nilai aset fisik. Pertambahan usia suami cenderung menurunkan tingkat kesejahteraan keluarga petani, hal ini dikarenakan tidak lagi berada di usia produktif. Sedangkan bertambahnya pendapatan keluarga per kapita dan besarnya nilai aset fisik dapat meningkatkan kesejahteraan keluarga petani.

Sedangkan Subaidi (2014) memberikan gambaran bahwa nafkah dapat diartikan sebagai kewajiban seorang suami, yang timbul dari beban tanggung jawab sebagai kepala rumah tangga, yaitu berupa pembiayaan untuk memenuhi kebutuhan baik primer maupun sekunder. Subaidi juga mencatat bahwa kemunculan hukum atas kewajiban pemberian nafkah dipengaruhi oleh tiga hal, yaitu: pertama, zaujiyyah, yaitu adanya ikatan pernikahan. Kedua, qarabah, yaitu adanya hubungan kekerabatan. Ketiga, milk, yaitu adanya kepemilikan, dalam hal ini kepemilikan budak (Subaidi, 2014).

Dalam kompilasi hukum Islam (KHI), ketentuan mengenai nafkah setidaknya ada tiga hal yang perlu diketahui, yaitu: pertama, konteks menafkahi keluarga wajib dijalankan selama berlangsungnya ikatan pernikahan sampai dengan ketika istri selesai 'iddah, tentunya selain perceraian akibat li'an dan nusyuz. Kedua, besaran nafkah yang wajib ditanggung oleh suami adalah berdasarkan kemampuannya. Ketiga, Pengadilan Agama harus memberikan solusi terbaik jika terjadi perselisihan terkait dengan pembayaran nafkah (Abdurrahman, 1992). Dari sini dapat disimpulkan bahwa dalam masalah nafkah, Islam 
sangat luwes dan fleksibel. Nafkah yang harus dibayarkan disesuaikan dengan kemampuan suami. Oleh sebab itu, yang diperlukan adalah kesepakatan bersama antara suami dan istri dalam menentukan besaran nafkah yang harus dibayarkan sesuai dengan kebutuhan dalam keluarganya. Terlebih lagi dalam kondisi suami yang memiliki keterbatasan fisik, atau dalam konteks di masa pandemi covid 19, dan lain sebagainya.

\section{Perekonomian Keluarga}

Warto (2015), dalam penelitiannya, menegaskan bahwa pada umumnya kondisi kemiskinan yang dialami petani di pelosok pedesaan dikarenakan belum sepenuhnya terpenuhi kebutuhan dasar, meliputi kebutuhan pangan, sandang, tempat tinggal, kesehatan, pendidikan, pekerjaan, serta kebutuhan sarana dan prasarana kehidupan, seprti belum terpenuhi kebutuhan informasi, komunikasi, dan teknologi. Di sisi lain, kemiskinan yang dialami oleh petani juga tergambarkan dalam bentuk tiadanya kesempatan kerja dan usaha, keterbatasan modal, dan bahkan sebagian masyarakat petani cenderung bersikap nrimo ing pandum (berserah pada nasib), serta sebagian lagi kurang memiliki etos kerja.

Di antara upaya untuk membangun perekonomian keluarga yang solid, perlu dilakukan analisis terhadap konsep sebaran kemiskinan di setiap daerah atau wilayah yang sedang diamati. Wilayah dengan tingkat sebaran kemiskinan yang tinggi diduga dapat dipengaruhi oleh wilayah lain yang juga memiliki tingkat kemiskinan yang tinggi pula (Sarah Nita Hasibuan, dkk, 2019). Dalam buku "Rahasia menjaga Ketahanan Ekonomi Keluarga" (BKKBN, 2017) menegaskan ada empat langkah yang dapat dilakukan untuk menjaga ketahanan ekonomi keluarga, yaitu: pertama, mampu mengatur keuangan keluarga. Dalam hal ini, setiap anggota saling bekerjasama secara kompak dalam mengatur keuangan keluarga dengan sebaik-baiknya. Kedua, memiliki pola hidup sederhana, yaitu hidup yang disesuaikan dengan kebutuhan atau tidak berlebihan. Ketiga, memiliki sumber penghasilan tambahan, agar dapat memenuhi dan menunjang berbagai kebutuhan rumah tangga. Keempat, memiliki beberapa aset keluarga, yaitu seperti aset sumber daya manusia, aset fisik (kekayaan fisik), aset kertas (saham), dan aset maya (berbasis internet).

Jadi, ketahanan dan kesejahteraan keluarga diupayakan agar kondisi keluarga memiliki ketangguhan serta mampu mengembangkan diri dan keluarga untuk meningkatkan kesejahteraan dan kebahagiaan lahir batin. Adapun tujuan dari konsep ketahanan kesejahteraan keluarga tersebut adalah untuk meningkatkan kesejahteraan keluarga, meningkatkan pengaturan keuangan keluarga, menyiapkan generasi yang bahagia dan sejahtera, serta menjadi keluarga yang mandiri pada masa yang akan datang (BKKBN, 2017).

\section{METODE PENELITIAN}

\section{Jenis Penelitian}

Penelitian ini termasuk ke dalam penelitian deskriptif, yaitu penelitian yang memiliki pola dan metode penelitian melalui proses datanya dapat memberi ruang pada peneliti untuk menghasilkan suatu gambaran nyata tentang fenomena sosial yang dijadikan sebagai obyek penelitian. Dengan data dalam bentuk deskriptif ini, peneliti dapat melakukan identifikasi 
mengenai mengapa, apa dan bagaimana suatu fenomena sosial dapat terjadi. Dari sini dapat diketahui bahwa tujuan utama penelitian ini, melalui pola deskriptif, menegaskan pada tiga hal, yaitu mendeskripsikan obyek penelitian melalui daya yang ada, menjelaskan obyek penelitian sesuai dengan data, dan melakukan validasi terhadap temuan atau hasil penelitian.

\section{Tahap Penelitian}

Adapun tahapan penelitian ini meliputi beberapa hal sebagai berikut, pertama, menentukan permasalahan. Penelitian ini memiliki rumusan masalah di antaranya: bagaimana konsep nafkah diberlakukan di masyarakat Desa Karangsari, bagaimana implementasi konsep nafkah dalam memberikan pengaruh terhadap kesejahteraan perekonomian masyarakat Desa Karangsari. Kedua, melakukan studi literatur, dengan menganalisis beberapa literatur yang ada, penelitian ini dapat memiliki arah dan tujuan yang berbeda dengan penelitian-penelitian sebelumnya. Ketiga, penetapan lokasi, sebagaimana diketahui bahwa lokasi penelitian adalah Desa Karangsari, yang termasuk desa yang paling aktif dalam mengadakan kegiatan keagamaan, dikarenakan memiliki dua orang tokoh yang menjadi penyuluh agama. Dengan demikian, lebih mudah dalam melakukan analisis data penelitian. Ketiga, studi pendahuluan. Penelitian ini melakukan upaya penelusuran terhadap beberapa studi yang pernah dilakukan, yang kemudian dianalisis beberapa hal yang menjadi distingtif dalam penelitian ini. Kelima, penetapan metode pengumpulan data, yaitu melalui observasi lapangan, wawancara dengan informan, mendokumentasi beberapa data penting, dan melakukan diskusi terarah dengan informan. Keenam, melakukan analisis data baik selama penelitian maupun setelahnya yang meliputi validasi dan reliabilitas. Ketujuh, melakukan pemaparan hasil penelitian dengan dukungan data penelitian yang didapatkan di tempat penelitian.

\section{Waktu dan Tempat Penelitian}

Penelitian ini dilakukan dalam rentang waktu tiga bulan, yaitu bulan Maret-Mei 2021 di Desa Karangsari Kecamatan Kembaran Kabupaten Banyumas.

\section{Metode Penggalian Data}

Dalam penggalian data penelitian, peneliti melakukan upaya wawancara dengan informan, melakukan observasi data di balai desa, dan melakukan forum group discussion (FGD) dengan beberapa pihak terkait.

\section{Profil Informan}

Informan yang diwawancarai adalah dua penyuluh agama Kecamatan Kembaran yang ditempatkan tugasnya di Desa Karangsari, yaitu Sodikin dan Nurhadi Cahyono. Dari keduanya diperoleh beberapa hal yang dapat membantu peneliti dalam mencari data dan menghasilkan penelitian. Dua informan ini diangkat menjadi penyuluh agama sejak 2017 dan asli putra daerah, sehingga betul-betul memahami tempat atau lokasi obyek penelitian. 


\section{HASIL DAN PEMBAHASAN}

\section{Hasil}

Data penelitian yang berkaitan dengan data lapangan, didapatkan dalam kisaran tahun 2018-2020 di kantor desa. Berdasarkan data yang didapatkan, Desa Karangsari Secara administratif, berada dalam wilayah Kecamatan Kembaran Kabupaten Banyumas dengan batas-batas wilayah sebagai berikut.
a. Sebelah Barat
: Desa Karangsoka
b. Sebelah Timur
: Desa Linggasari
c. Sebelah Selatan
: Desa Kembaran
d. Sebelah Utara
: Desa Bantarwuni

Adapun luas wilayah Desa Karangsari adalah tergambar dalam data berikut ini.

Tabel 1. Lahan Wilayah Desa Karangsari

\begin{tabular}{ll}
\hline Lahan & Luas \\
\hline Persawahan & $79,200 \mathrm{Ha}$ \\
Pemukiman & $30,680 \mathrm{Ha}$ \\
Peternakan & $0,98 \mathrm{Ha}$ \\
Perikanan & $2,82 \mathrm{Ha}$ \\
Pertokoan & $1 \mathrm{Ha}$ \\
Industri & $7 \mathrm{Ha}$ \\
\hline
\end{tabular}

Sementara itu, data mengenai jumlah penduduk dengan komposisi usia penduduk dan berdasarkan jenis kelamin, didapatkan data sebagai berikut.

Tabel 2: Jumlah Penduduk Berdasarkan Usia dan Jenis Kelamin

\begin{tabular}{llll}
\hline Usia (th) & Laki-laki & Perempuan & Jumlah \\
\hline $0-4$ & 252 & 320 & 572 \\
$5-9$ & 240 & 266 & 506 \\
$10-14$ & 172 & 195 & 367 \\
$15-19$ & 157 & 76 & 233 \\
$20-24$ & 190 & 220 & 410 \\
$25-29$ & 168 & 191 & 359 \\
$30-39$ & 152 & 208 & 360 \\
$40-49$ & 154 & 168 & 322 \\
$50-59$ & 144 & 162 & 306 \\
$>60$ & 142 & 136 & 278 \\
\hline Jumlah & $\mathbf{1 7 7 1}$ & $\mathbf{1 9 4 2}$ & $\mathbf{3 7 1 3}$ \\
\hline
\end{tabular}

Selanjutnya, kondisi sosial ekonomi setiap kepala keluarga tergambarkan sebagai berikut:

Tabel 3. Kondisi Sosial Ekonomi Desa Karangsari

\begin{tabular}{llc}
\hline No & \multicolumn{1}{c}{ Keterangan } & Jumlah KK \\
\hline 1 & Keluarga Miskin & 301 \\
2 & Keluarga Menengah & 538 \\
3 & Keluarga Menengah Ke atas & 143 \\
\hline & Jumlah & $\mathbf{9 8 2}$ \\
\hline
\end{tabular}


Sedangkan tempat ibadah bagi umat Islam di Desa Karangsari berdasarkan data didapat keterangan sebagai berikut:

Tabel 4. Kondisi Tempat Ibadah Desa Karangsari

\begin{tabular}{cc}
\hline Tempat Ibadah & Jumlah \\
\hline Masjid & 1 Buah \\
Musholla & 15 Buah \\
\hline
\end{tabular}

Sementara itu, pekerjaan para penduduk di Desa Karangsari berdasarkan data adalah sebagai berikut:

Tabel 5: Kondisi Sosial Ekonomi Desa Karangsari

\begin{tabular}{ccc}
\hline \multicolumn{2}{c}{ Mata Pencaharian } \\
\hline No & \multicolumn{1}{c}{ Pekerjaan } & Jumlah \\
\hline 1 & Petani & \\
& a. Petani Pemilik Sawah & orang \\
& b. Petani Penggarap Sawah & 37 orang \\
& c. Buruh Tani & 76 orang \\
3 & Pengusaha Sedang & 2 orang \\
4 & Pengrajin/industri & 10 orang \\
5 & Pedagang & 35 orang \\
6 & PNS & 45 orang \\
7 & Pensiunan & 6 orang \\
8 & Peternak & 24 orang \\
& a. Ternak Sapi & 20 orang : 48 ekor \\
& b. Ternak Kerbau & 2 orang : 5 ekor \\
& c. Ternak Kambing & 45 orang : 120 ekor \\
& d. Ternak Ayam Kampung & 104 orang : \pm 2500 ekor
\end{tabular}

Kemudian, dari data yang ada, tingkat pendidikan penduduk Desa Karangsari didapatkan gambaran sebagai berikut:

Tabel 6. Kondisi Tingkat Pendidikan Desa Karangsari

\begin{tabular}{cll}
\hline No & Pendidikan & Jumlah \\
\hline 1 & S2 & 10 orang \\
2 & S1 & 63 orang \\
3 & D3 & 37 orang \\
4 & D2 & 25 orang \\
5 & D1 & 20 orang \\
6 & Tamat SLTA & 513 orang \\
7 & Tamat SLTP & 611 orang \\
8 & Tamat SD & 1317 orang
\end{tabular}




\begin{tabular}{cll}
\hline No & Pendidikan & Jumlah \\
\hline 9 & Belum Tamat SD & 392 orang \\
10 & Tidak Tamat SD & 356 orang \\
11 & Belum Sekolah & 379 orang \\
\hline & Jumlah Total & 3713 orang \\
\hline
\end{tabular}

Berdasarkan data di atas, dapat diidentifikasi bahwa masyarakat miskin Desa Karangsari berakar dari kurangnya sumber daya manusia (SDM), dalam hal ini adalah tidak terpenuhinya tingkat wajib belajar 9-12 tahun. Terbukti dalam data yang ada, setengah dari seluruh jumlah penduduk yang terdata masih berada di bawah pendidikan SLTA. Dari sini dapat dirumuskan hasil penelitian dari data tersebut bahwa ketika prosentase masyarakat yang berpendidikan tinggi lebih dominan jumlahnya, maka kesejahteraan perekonomian masyarakat menjadi terjamin. Akan tetapi, jika sebaliknya, inovasi dalam mengembangkan kesejahteraan perekonomian keluarga sulit terwujud dikarenakan penduduk masih berpendidikan rendah. Dengan demikian, implementasi konsep nafkah yang merupakan upaya memenuhi kebutuhan dasar rumah tangga, sedikit banyak dipengaruhi oleh faktor pendidikan. Dari data yang ada, masyarakat miskin Desa Karangsari lebih didominasi oleh masyarakat dengan pendidikan rendah dan kurang mendapatkan pelatihan serta ketrampilan, pada akhirnya pendapatan rumah tangga rendah. .

Kesadaran dalam menerapkan konsep nafkah memberikan dorongan tersendiri bagi kepala rumah tangga untuk setidaknya memikirkan nasib keluarganya. Hal ini dikarenakan dalam membangun rumah tangga adalah suatu yang kompleks dan tidak sederhana. Dalam Islam, Pendekatan kebutuhan dasar dikelompokkan ke dalam tiga hal (Asy-Syatibi, 2004), yaitu sebagai berikut, pertama, kebutuhan yang sifatnya primer atau pokok (ضرورية). Dapat dikatakan bahwa kemiskinan adalah ketidakmampuan seseorang, keluarga dan masyarakat dalam memenuhi kebutuhan dasar minimum, seperti kebutuhan makanan pokok, pakaian, tempat tinggal, pelayanan kesehatan, pendidikan, penyediaan air bersih dan sanitasi. Kedua, kebutuhan sekunder (حاجية). Melalui pendekatan kebutuhan ini, kemiskinan disebabkan di antaranya oleh ketidakmampuan dalam memiliki penghasilan tambahan, seperti rendahnya penguasaan aset dan alat-alat produktif. Kurangnya keluarga dalam mengupayakan kebutuhan mempengaruhi pendapatan seseorang dalam keluarga. Ketiga, kebutuhan tersier (تحسينية). Pendekatan kebutuhan ini menilai kemiskinan sebagai keterbatasan kemampuan dasar menyerap informasi, gagap teknologi, dan lain sebagainya.

Sementara itu, pendekatan kesejahteraan (the welfare approach) (Makarius Erwin Bria \& Suharno Suharno, 2018) menekankan pada penilaian yang bersifat normatif dan ketentuan yang harus dipenuhi agar keluar dari kemiskinan. Pendekatan kesejahteraan tersebut terdiri dari beberapa hal, yaitu: pertama, pembangunan dan peningkatan infrastruktur. Kedua, peningkatan kesejahteraan masyarakat melalui berbagai program yang direncanakan oleh pemerintah.

Dari pendekatan-pendekatan konsep nafkah tersebut di atas, dapat disimpulkan bahwa indikator utama kemiskinan dapat teridentifikasi dari beberapa hal berikut. Pertama, kurang 
terpenuhinya makanan pokok, pakaian dan rumah tinggal yang tidak layak. Kedua, adanya keterbatasan kepemilikan tanah dan alat-alat produktif. Ketiga, kurangnya kemampuan membaca dan menulis serta keterbatasan dalam menyerap informasi dan gagap teknologi. Keempat, minimnya jaminan dan kesejahteraan hidup; sehingga terjadi kerentanan dan keterpurukan dalam bidang sosial dan ekonomi. Kelima, kurangnya akses terhadap ilmu pengetahuan.

Dari serangkaian penyebab kemiskinan masyarakat desa yang telah disebutkan di atas, implementasi konsep nafkah dalam upaya meningkatkan kesejahteraan ekonomi di desa Karangsari dapat dilakukan dengan cara mengoptimalkan pentasarrufan nafkah pada beberapa titik yang digambarkan dalam tabel sebagai berikut:

\section{Tabel 7. Implementasi Nafkah Keluarga di Desa Karangsari}

\begin{tabular}{ll}
\hline \multicolumn{3}{c}{ Implementasi nafkah pada keluarga di Desa Karangsari } \\
\hline Pendidikan & Mengupayakan seluruh anggota keluarga mendapatkan \\
& layanan pendidikan yang memadai. Tentunya hal ini dapat \\
& diintegrasikan dengan bantuan dari pemerintah yang \\
& diorientasikan pada penduduk miskin \\
& Mengupayakan seluruh anggota keluarga mendapatkan \\
Ekonomi & kebutuhan ekonomi yang memadai. Hal ini dapat \\
& dilakukan melalui upaya mengotimalkan pengelolaan \\
& lahan tanah yang ada. Terlebih lagi Desa Karangsari \\
& memiliki banyak lahan subur. \\
Makanan dan & Mengupayakan seluruh anggota keluarga mendapatkan \\
minuman & suplai makanan dan minum yang memadai. \\
Tempat Tinggal & Mengupayakan seluruh anggota keluarga mendapatkan \\
Pakaian & tempat tinggal yang memadai dan layak huni. \\
Kengupayakan seluruh anggota keluarga mendapatkan \\
Menatan
\end{tabular}

Implementasi nafkah tidak dapat maksimal jika tidak disertai dengan dukungan dari masyarakat dan pemerintah setempat. Oleh karena itu, pemerintah perlu didorong agar merealisasikan beberapa program alternatif untuk memberikan kesejahteraan kepada setiap keluarga di Desa Karangsari. Upaya program yang dapat oleh pemerintah setempat di antaranya digambarkan dalam tabel sebagai berikut:

Tabel 8. Program alternatif Pemerintah

\begin{tabular}{ll}
\hline Program alternatif pemerintah dalam meningkatkan kesejahteraan Keluarga \\
\hline Investasi & mendorong perkembangan investasi pertanian. Dengan \\
adanya pembukaan investasi pertanian dapat memberikan \\
kesempatan kerja kepada masyarakat, sehingga \\
pendapatan mereka akan meningkat dan berpengaruh pada \\
perubahan kesejahteraan hidup
\end{tabular}




\begin{tabular}{|c|c|}
\hline \multicolumn{2}{|c|}{ Program alternatif pemerintah dalam meningkatkan kesejahteraan Keluarga } \\
\hline Kredit & $\begin{array}{l}\text { membuka kesempatan yang luas kepada masyarakat desa } \\
\text { untuk memperoleh kredit usaha yang mudah }\end{array}$ \\
\hline Kebutuhan dasar & $\begin{array}{l}\text { memberikan kesempatan yang sama kepada masyarakat } \\
\text { desa untuk memperoleh sumber-sumber kebutuhan yang } \\
\text { disediakan secara terorganisir }\end{array}$ \\
\hline Teknologi & $\begin{array}{l}\text { Mengupayakan sistem pertanian modern dengan teknologi } \\
\text { baru yang memberikan kemudahan bagi masyarakat untuk } \\
\text { menggali sumber-sumber pendapatan yang memadai. Di } \\
\text { samping itu untuk meningkatkan produktivitas pertanian } \\
\text { dan mempermudah pemenuhan kebutuhan hidup } \\
\text { masyarakat }\end{array}$ \\
\hline Kesehatan & $\begin{array}{l}\text { mengupayakan jaminan kesehatan kepada mayarakat } \\
\text { dengan sistem layanan kesehatan gratis, memperbanyak } \\
\text { unit-unit layanan kesehatan kepada masyarakat }\end{array}$ \\
\hline $\begin{array}{l}\text { Asuransi dan } \\
\text { jaminan sosial }\end{array}$ & $\begin{array}{l}\text { Mengupayakan adanya jaminan asuransi dan jaminan } \\
\text { sosial terhadap masyarakat desa, yang bertujuan untuk } \\
\text { meningkatkan kualitas hidup masyarakat miskin serta } \\
\text { tidak ada diskriminasi dalam pelaksanaannya }\end{array}$ \\
\hline Agenda & Mendorong agenda prioritas dalam pemberantasan \\
\hline Pembangunan & $\begin{array}{l}\text { kemiskinan dan meningkatkan kesejahteraan } \\
\text { perekonomian keluarga }\end{array}$ \\
\hline
\end{tabular}

Sementara itu, dalam implementasi konsep nafkah, para tokoh agama juga harus dilibatkan, khususnya peran penyuluh agama setempat perlu dioptimalkan. Hal ini penting dikarenakan konsep nafkah berasal dari ajaran agama dan harus disosialisasikan oleh seseorang yang memahami agama, atau setidaknya yang bergerak di bidang keagamaan. Penyuluh Agama Islam harus bersedia dengan tulus dalam melaksanakan amanah yang cukup berat ini, di mana ia harus mampu bertindak selaku motivator, fasilitator, dan sekaligus katalisator dakwah Islam. Manajemen dakwah harus dapat dikembangkan dan diaktualisasikan sesuai dengan perkembangan masyarakat yang sedang mengalami perubahan. Penyuluh agama dapat merefleksikan dan mengaktualisasikan pemahaman, penghayatan dan pengamalan nilai-nilai keimanan dan ketaqwaan dalam konteks kehidupan bermasyarakat, berbangsa dan bernegara. Khusus terkait implementasi konsep nafkah, penyuluh agama harus memberi ilustrasi nyata kenapa Islam memberlakukan konsep nafkah dalam kehidupan berumah tangga.

\section{Pembahasan}

Sebagaimana terlihat di atas, ketika konsep nafkah tidak dijalankan secara maksimal, maka beberapa motif kemiskinan dapat teridentifikasi, di antaranya sebagai berikut. Pertama, adanya kelemahan. Kelemahan inijkyh meliputi kelemahan hati, lemah semangat, kelemahan akal, kelemahan ilmu, dan kelemahan fisik. Kelemahan ini dapat mengurangi kemampuan manusia dalam menjalankan fungsi dalam kehidupannya. Kedua, adanya kemalasan. Tidak diragukan lagi bahwa sifat malas merupakan pangkal utama dari munculnya kemiskinan. Ketika seorang suami malas mencari pekerjaan untuk menafkahi keluarga, maka kesejahteraan perekonomian keluarga tidak akan terwujud. Oleh 
karena itu, konstruksi kehidupan yang diajarkan oleh Islam sangat bertolak belakang dengan sifat malas tersebut. Ketiga, adanya ketakutan. Sikap takut merupakan salah satu penghambat utama dalam mencapai suatu sukses pekerjaan dan usaha. Sisi keberhasilan seseorang banyak tergantung dari keberanian yang ada pada dirinya. Keempat, kepelitan. Sikap pelit tidak dapat membantu untuk mengurangi kemiskinan, karena kekayaan akan tertimbun pada orang-orang yang kaya. Kelima, terlilit hutang. Orang yang pada umumnya membiayai hidupnya dari hutang akan sulit sekali mengangkat dirinya dari kemiskinan. Keenam, selalu diperas atau dikuasai sesama manusia. Kondisi seperti ini merupakan penyebab bagi timbulnya banyak penderitaan. Dapat diketahui dari sejarah penjajahan, ada kenyataaan bahwa betapa besar kemiskinan yang menyengsarakan masyarakat Indonesia saat itu, sehingga mudah sekali ditindas oleh siapapun yang memiliki kekayaan. Dengan demikian, kemiskinan dan tidak adanya kesejahteraan keluarga, berkaitan erat dengan kondisi anggota keluarga itu sendiri, misalnya kurang percaya diri pada kemampuan, enggan mengaktualisasikan potensi yang ada, tidak respek terhadap perubahan, dan lain sebagainya.

Loekman Soetrisno (1997), mengutip pendapat Robert Chambers, menyatakan bahwa kemiskinan disebabkan oleh beberapa faktor yang dikenal sebagai ketidakberuntungan atau disadvantages yang saling terkait. Menurut Robert Chambers, ada lima "ketidakberuntungan" yang melingkari kehidupan keluarga miskin, yaitu: Pertama, adanya kemiskinan (poverty), dengan ditandai dengan tempat tinggal yang tidak layak huni, perlengkapan rumah tangga tidak lengkap, dan pendapatan tidak menentu. Kedua, adanya fisik yang lemah (physical weakness); keluarga miskin lemah secara fisik akibat rendahnya gizi, beban kerja terlalu berat dan sering berinteraksi dengan berbagai bibit macam penyakit akibat kemiskinan. Ketiga, adanya keterasingan (isolation). Keluarga miskin dapat terasing di antaranya karena mereka tidak memiliki akses terhadap sumber-sumber informasi. Keempat, adanya kerentanan (vulnerability) akibat kondisi sosial ekonomi yang tidak stabil. Kelima, adanya ketidakberdayaan (powerlessness). Orang miskin tidak berdaya terhadap eksploitasi yang dialaminya.

Dari sini, dapat dinyatakan bahwa implementasi konsep nafkah pada keluarga, khususnya di Desa Karangsari harus menjadi perhatian penuh bagi siapapun yang akan membangun rumah tangga. Keluarga adalah masyarakat terkecil yang dapat diupayakan kesejahteraannya melalui konsep nafkah. Rumah tangga ibarat suatu negara, sementara pemimpin negara diibaratkan seorang suami. Oleh sebab itu, suami memiliki tanggungjawab yang sama sebagaimana seorang pemimpin dalam mengatur negara. Kebijakan seorang pemimpin harus berlandaskan pada kemaslahatan rakyat yang dipimpinnya.

Ketika kesadaran akan pentingnya konsep nafkah dalam keluarga, tentunya akan menjadi perhatian semua pasangan sebelum melangkah pada jenjang pernikahan. Di sisi lain, akan terbangun tanggungjawab, khususnya seorang suami, dalam memberikan kesejahteraan kepada segenap anggota keluarganya. Ketika setiap keluarga sejahtera, maka masyarakat pun sejahtera dan negara pun akan semakin maju dan bermartabat. Tujuan 
seperti ini harus senantiasa didukung oleh berbagai pihak agak terciptanya kehidupan yang damai dan sejahtera, sehingga konsentrasi dalam beribadah akan tercipta dengan baik.

\section{E. KESIMPULAN}

Dari uraian di atas, dapat disimpulkan beberapa hal sebagai berikut. Pertama, konsep nafkah adalah syariat agama Islam yang memberikan efek kemaslahatan terhadap keluarga dan menghindarkan berbagai macam efek kemafsadatan. Kedua, berdasarkan data, keluarga di Desa Karangsari belum dapat dikatakan sejahtera perekonomiannya, karena angka kemiskinan masih tinggi dan hasil ini searah dengan minimnya tingkat pendidikan dari tiap-tiap anggota keluarga. Ketiga, kesejahteraan perekonomian keluarga dapat diupayakan melalui implementasi konsep nafkah. Konsep ini perlu didukung oleh berbagai alternatif program pemerintah dan juga perlu disosialisasikan oleh tokoh agama setempat, khususnya penyuluh agama Islam setempat.

Hasil penelitian menunjukkan bahwa bidang pendidikan memiliki peran penting dalam memberikan efek kesadaran bagi kepala keluarga dalam kewajibannya mentasarufkan nafkah untuk kesejahteraan perekonomian keluarga. Pada saat kepala keluarga memiliki pendidikan rendah dampaknya adalah kurang optimalnya pemberian nafkah sebagai poros utama dalam membangun kesejateraan keluarga dan ketika implementasi nafkah kurang optimal akibatnya kesejahteraan perekonomian keluarga tidak dapat tercapai dengan baik.

Implikasi dari penelitian ini adalah adanya upaya uuntu mengubah mindset keluarga dalam mengembangkan potensi keluarga dam mindset akan pentingnya membangun ekonomi keluarga melalui nafkah, membuat lapangan pekerjaan keluarga, bukan hanya untuk diri sendiri, tapi juga membangun cita-cita masa depan untuk menyelamatkan kesejahteraan ekonomi keluarga. Di samping itu, perlu membangun pola pikir, bahwa dengan memaksimalkan nafkah kehidupan ekonomi keluarga menjadi stabil.

Adapun rekomendasi yang dapat disampaikan untuk dilakukan follow up di antaranya sebagai berikut. Pertama, penelitian ini masih sebatas pemaparan bahwa pengaruh konsep nafkah terhadap kesejahteraan keluarga adalah signifikan, belum sampai merambah pada upaya yang dilakukan agar setiap keluarga memiliki kemampuan dalam mengoptimalkan nafkah. Kedua, penelitian ini belum memaparkan upaya beberapa pihak, khususnya pemerintah, dalam menanggulangi kemiskinan dan upaya mensejahterakan keluarga. Ketiga, penelitian ini belum memberikan gambaran rinci terkait peran tokoh-tokoh agama dalam memberi pencerahan tehadap ajaran agama yang berimplikasi pada sosial kemasyarakatan.

\section{DAFTAR PUSTAKA}

Arifin, Johan (2020), Budaya Kemiskinan Dalam Penanggulangan Kemiskinan Di Indonesia. Jurnal Sosio Informa: Kajian Permasalahan Sosial dan Usaha Kesejahteraan Sosial, 6(2), 114-131. DOI: https://doi.org/10.33007/inf.v6i2.2372

Hidayati, Farida, dkk. (2012), Peran Ayah Dalam Pengasuhan Anak, Jurnal Psikologi, 9 (1), 1 10. https://doi.org/10.14710/jpu.9.1. 
Arif Rahman, H. A. (2021). Kewajiban Suami Memberi Nafkah Dalam Kompilasi Hukum Islam. Jurnal al-iqtishod, $5 \quad$ (1), 16-27. Retrieved from http://ejournal.kopertais4.or.id/tapalkuda/index.php/IQTISHOD/article/view/4194.

Rozali, Ibnu (2017), “Konsep Memberi Nafkah bagi Keluarga dalam Islam”, Jurnal Intelektualita: Keislaman, Sosial dan Sains, 6, (2), 189-202. DOI https://doi.org/10.19109/intelektualita.v6i2.1605.

F., Tyas Eko Raharjo (2013), Strategi Keluarga Miskin dalam Mengatasi Kemiskinan, Jurnal Penelitian Kesejahteraan Sosial, 12 (2), 115-132. Retrieved from https://ejournal.kemsos.go.id/index.php/jpks/article/view/650/285.

Wahbah al-Zuhaili, al-Fiqh al-Islam wa Adillatuhu, (Beirut: Dar al-Fikr, 1989), jilid II, cet. II, hal. 765.

Suryawati, Chriswardani (2005), Memahami Kemiskinan Secara Multidimensional, Jurnal Manajemen pelayanan Kesehatan, 8 (3), 121-129. Retrieved from https://jurnal.ugm.ac.id/jmpk/article/view/2927.

Ikawati, \& Sri Wahyuni (2016), Kondisi Kemiskinan Di Perdesaan Dan Perkotaan, Jurnal Media Informasi Penelitian Kesejahteraan Sosial, 40 (2), 191-202. DOI: https://doi.org/10.31105/mipks.v40i2.2295.

Ginanjar, Kartasasmita. (1996). Pembangunan Untuk Rakyat. Jakarta: PT. Pustaka Cidosindo. Cica sartika, dkk. (2016), Studi Faktor-Faktor Penyebab Kemiskinan Masyarakat Desa Lohia Kecamatan Lohia Kabupaten Muna, Jurnal Ekonomi (je), 1(1), 106-118 e-issn: 25031937. Http://ojs.uho.ac.id/index.php/je.

Sugiharto, A., dkk. (2016). Jurnal Ilmu Keluarga \& Konsumen, 9(1), 33-42. https://doi.org/10.24156/jikk.2016.9.1.33.

Sevrianda, Ichsan \& Dewi Zaini Putri (2018), Karakteristik Rumah Tangga Miskin Perkotaan Dan Pedesaan Di Sumatera Barat, Jurnal Ecogen, 1 (3), 673-680. Retrieved from http://ejournal.unp.ac.id/students/index.php/pek/article/view/5113/2773.

Adam Sugiharto, dkk. (2016), Strategi Nafkah dan Kesejahteraan Keluarga Pada Keluarga Petani Tadah Hujan, Jurnal Ilmu Keluarga dan Konsumen, 9 (1), 33-42, ISSN : 1907 6037 e-ISSN : 2502 - 3594, DOI:10.24156/jikk.2016.9.1.33.

Warto (2015), Kondisi Kemiskinan Petani dan Upaya Penanggulangannya, Jurnal Penelitian Kesejahteraan Sosial, 14 (1), 20-29, DOI: https://doi.org/10.31105/jpks.v14i1 .

Hasan, M. Ali, (2006), Pedoman Hidup Berumah Tangga dalam Islam, Jakarta: Prenada Media Group.

Sarah Nita Hasibuan, Dkk. (2019), Analisis Sebaran Dan Faktor Penyebab Kemiskinan Di Kabupaten Bandung Barat, Jurnal Agribisnis Indonesia (Journal Of Indonesian Agribusiness), 7 (2), 79-91, Issn 2354-5690: E-Issn 2579-3594 Https://Doi.Org/10.29244/Jai.2019.7.2.79-91.

Subaidi (2014), Konsep Nafkah Menurut Hukum Perkawinan Islam, ISTI'DAL; Jurnal Studi $\begin{array}{lllll}\text { Hukum Islam, } & 1 & \text { (2), } & \text { 157-169, } & \text { ISSN: }\end{array}$

DOI: https://doi.org/10.34001/istidal.v1i2.

Abdurrahman (1992), Kompilasi Hukum Islam di Indonesia, t,t, : Akademika Pressindo. 
BKKBN (2017), Rahasia Menjaga Ketahanan Ekonomi Keluarga, Jakarta: Direktorat Pemberdayaan Ekonomi Keluarga.

Asy-Syatibi (2004), Al-Muwafaqat fi usul asy-Syari'ah, Beirut: Dar al-Kutub al-'Ilmiyyah, juz II.

Makarius Erwin Bria \& Suharno Suharno (2018), Pendekatan Kesejahteraan Sebagai Strategi Penguatan Nasionalisme Masyarakat Di Kawasan Perbatasan, Jurnal Ilmiah Pendidikan Pancasila dan Kewarganegaraan, $31-88$, DOI: http://dx.doi.org/10.17977/um019v3i12018p081.

Sutrisno, Loekman (1997), Kemiskinan, Perempuan, dan Pemberdayaan, Yogyakarta: Kanisius. 